\title{
Hydrogen Peroxide: A Potential Wound Therapeutic Target?
}

\author{
Guanya Zhu Qi Wang Shuliang Lu Yiwen Niu
}

Department of Burns and Plastic Surgery, Ruijin Hospital, Shanghai Jiao Tong University School of Medicine, Shanghai, China

\section{Significiance of the Study}

- Currently, effective and practical treatments of chronic wounds are still clinical challenges. The main clinical use of hydrogen peroxide $\left(\mathrm{H}_{2} \mathrm{O}_{2}\right)$ is to clean wounds for disinfection in a concentration of $3 \%$. With advances in research, $\mathrm{H}_{2} \mathrm{O}_{2}$ at $\mu \mathrm{M}$ levels has been reported to act as a signaling molecule which drives redox-sensitive signaling mechanisms to improve dermal wound healing. This review discussed the roles of $\mathrm{H}_{2} \mathrm{O}_{2}$ in cutaneous wound healing and its future use in treating chronic wounds.

\section{Keywords}

Hydrogen peroxide $\cdot$ Wound healing $\cdot$ Therapeutic target

\footnotetext{
Abstract

Hydrogen peroxide $\left(\mathrm{H}_{2} \mathrm{O}_{2}\right)$ is a topical antiseptic used in wound cleaning which kills pathogens through oxidation burst and local oxygen production. $\mathrm{H}_{2} \mathrm{O}_{2}$ has been reported to be a reactive biochemical molecule synthesized by various cells that influences biological behavior through multiple mechanisms: alterations of membrane potential, generation of new molecules, and changing intracellular redox balance, which results in activation or inactivation of different signaling transduction pathways. Contrary to the traditional viewpoint that $\mathrm{H}_{2} \mathrm{O}_{2}$ probably impairs tissue through its high oxidative property, a proper level of $\mathrm{H}_{2} \mathrm{O}_{2}$ is considered an important requirement for normal wound healing. Although the present clinical use of $\mathrm{H}_{2} \mathrm{O}_{2}$ is still limited to the elimination of microbial contamination and sometimes hemostasis, better understanding towards the sterilization ability and cell behavior regulatory function of $\mathrm{H}_{2} \mathrm{O}_{2}$ within wounds will enhance the potential to exogenously augment and manipulate healing.

ㄷ) 2017 S. Karger AG, Basel

\begin{tabular}{ll}
\hline KARGER & (c) 2017 S. Karger AG, Basel \\
$\begin{array}{l}\text { E-Mail karger@karger.com } \\
\text { www.karger.com/mpp }\end{array}$ & $\begin{array}{l}\text { This is an Open Access article licensed under the terms of the } \\
\text { Creative Commons Attribution-NonCommercial 3.0 Un- } \\
\text { ported license (CC BY-NC) (www.karger.com/OA-license), } \\
\text { applicable to the online version of the article only. Distribu- } \\
\text { tion permitted for non-commercial purposes only. }\end{array}$
\end{tabular}
}

\section{Introduction}

Among various reactive oxygen species (ROS), hydrogen peroxide $\left(\mathrm{H}_{2} \mathrm{O}_{2}\right)$ is relatively poorly reactive, which allows it to migrate further from its site of generation to serve as a signaling molecule or second messenger [1]. When a cutaneous injury happens, the concentration of $\mathrm{H}_{2} \mathrm{O}_{2}$ in surrounding tissue rises immediately and then peaks and fades away [2]. This dynamic change of $\mathrm{H}_{2} \mathrm{O}_{2}$ level accompanies the wound healing course and the concentration of $\mathrm{H}_{2} \mathrm{O}_{2}$ in wound tissue influences the outcome to a certain extent.

Wound healing is a tightly controlled process in which $\mathrm{H}_{2} \mathrm{O}_{2}$ plays multiple functions. Apart from killing microorganisms, $\mathrm{H}_{2} \mathrm{O}_{2}$ also serves as a signaling molecule or second messenger which delivers a damage message and stimulates effector cells to respond [3]. $\mathrm{H}_{2} \mathrm{O}_{2}$ regulates gene expression through several ways: synthesis of more transcription factors; inhibiting the ubiquitin E3 ligase complex or decreasing transcription factors associated

Guanya Zhu and Qi Wang contributed equally to this work.

Yiwen Niu

Department of Burns and Plastic Surgery

Ruijin Hospital, Shanghai Jiao Tong University School of Medicine

Shanghai (China)

E-Mail 13636489036@163.com 
with it to promote stability of the transcription factor; exposing/masking nuclear localization signals; and modulating transcription factor affinity towards deoxyribonucleic acid, coactivators, or repressors [4]. The transcription factors that receive the modulation of $\mathrm{H}_{2} \mathrm{O}_{2}$ are diverse, including Escherichia coli OxyR, NF- $\kappa \mathrm{B}$, activator protein-1, hypoxia-inducible factor-1, etc. These diverse actions could explain the broad impact brought by $\mathrm{H}_{2} \mathrm{O}_{2}$ [4].

The biological effect of $\mathrm{H}_{2} \mathrm{O}_{2}$ is dose dependent during the wound-healing process. For example, in relatively high concentrations, $\mathrm{H}_{2} \mathrm{O}_{2}$ displays its strong ability of oxidization and proinflammation to disinfect wound tissue; however, in comparatively low concentrations, $\mathrm{H}_{2} \mathrm{O}_{2}$ assists in removing cell and pathogen debris and promotes secretion of cytokines which help tissue regeneration [5-7]. Hence, in this review, the role of $\mathrm{H}_{2} \mathrm{O}_{2}$ in cutaneous wound healing and its potential as a chronic wound healing agent are discussed.

\section{The Production of Endogenous Hydrogen Peroxide after Cutaneous Injury}

$\mathrm{H}_{2} \mathrm{O}_{2}$ is produced in aerobic cells as a byproduct of aerobic respiration or an output of enzymatic reactions in mitochondria, peroxisomes, or other cell compartments $[8,9]$. The production of $\mathrm{H}_{2} \mathrm{O}_{2}$ is maintained at a low level under basic conditions because of its reactivity with intracellular antioxidant systems that include ascorbic acid, glutathione, catalase, and other antioxidants [10].

Once a skin wound occurs, based on an experiment performed on zebrafish by mechanically injuring its tail fin, a sustained rise in $\mathrm{H}_{2} \mathrm{O}_{2}$ concentration was detected at the wound margin immediately after the injury occurred [2]. The $\mathrm{H}_{2} \mathrm{O}_{2}$ gradient recruited leukocytes to the wound site which peaked about $20 \mathrm{~min}$ after occurrence of the injury and then gradually decreased [2]. Hence, the $\mathrm{H}_{2} \mathrm{O}_{2}$ produced after injury is a chemotactic signal as well as an inflammatory initiator.

The production of $\mathrm{H}_{2} \mathrm{O}_{2}$ after damage is mainly mediated by nicotinamide adenine dinucleotide phosphate (NADPH) oxidase, an enzyme which has at least 7 isomers $\left(\mathrm{NOX}_{1}, \mathrm{NOX}_{2}, \mathrm{NOX}_{3}, \mathrm{NOX}_{4}, \mathrm{NOX}_{5}, \mathrm{DUOX}_{1}\right.$, and $\left.\operatorname{DUOX}_{2}\right)[3,11]$. It is expressed mainly on the plasma membrane and subcellular membranes such as the mitochondrial and endoplasmic reticulum membrane [12, 13]. Multiple factors can induce the activation of $\mathrm{NADPH}$ oxidase such as mechanical injury, pathogen attack, and inflammatory cytokines $[11,14]$. After activa- tion, NADPH oxidase will convert one oxygen molecule into a superoxide anion $\left(\mathrm{O}_{2}^{-}\right)$which quickly transforms into $\mathrm{H}_{2} \mathrm{O}_{2}$ under the effect of superoxide dismutase [9].

\section{Regulatory Role of Hydrogen Peroxide in Wound Healing}

\section{Hemostasis Stage}

Vascular destruction often appears in cutaneous wounds, resulting in blood loss and evasion of pathogens. Hence, hemostasis is the first step to restore blood volume and reduce infection. $\mathrm{H}_{2} \mathrm{O}_{2}$ facilitates hemostasis with several plausible mechanisms that include activating latent cell surface tissue factor, platelet aggregation, stimulating platelet-derived growth factor activation and regulating the contractility and barrier function of endothelial cells [15].

\section{Inflammatory Reaction Stage}

Inflammation disinfects wound tissue to prepare a suitable environment for cell proliferation. $\mathrm{H}_{2} \mathrm{O}_{2}$ in wound tissue increases significantly during the inflammatory reaction stage to act as a potent inflammatory initiator and promoter [16].

The earliest immune cells arriving at the wound site are neutrophils and macrophages. They possess powerful abilities of engulfing evading microorganisms and killing them with proteases and elastase in granules [17]. Both ROS and protease are important for a phagocyte's killing efficacy [18]. The generation of ROS causes an influx of potassium ions $\left(\mathrm{K}^{+}\right)$into the phagocytic vacuole with an attendant rise in $\mathrm{pH}$ to the optimal level for the activity of the granule proteases [19]. $\mathrm{H}_{2} \mathrm{O}_{2}$ also induces mRNA expression of macrophage inflammatory protein- $1 \alpha$, macrophage inflammatory protein-2, and macrophage chemokine protein-1, which works as chemoattractant to recruit phagocytes [20-22]. Cellular adhesion molecules, such as intercellular adhesion molecule- 1 and leukocyte function-associated antigen-1, can promote leukocyte endothelial adhesion and assist in leukocytoplania. Their expressions are also elevated in the presence of $\mathrm{H}_{2} \mathrm{O}_{2}[23$, 24]. The recruitment of phagocytes is an essential step to initiate inflammation while insufficient phagocyte assembling often results in infection that hinders the wound-healing course [25].

$\mathrm{H}_{2} \mathrm{O}_{2}$ helps with the production of some molecules with higher oxidative potential and stronger bactericidal ability. For example, $\mathrm{H}_{2} \mathrm{O}_{2}$ oxidizes pseudohalide thiocyanate $(\mathrm{SCN}-)$ to generate hypothiocyanite $(\mathrm{HOSCN})$
302

Med Princ Pract 2017;26:301-308 DOI: $10.1159 / 000475501$
Zhu/Wang/Lu/Niu 
under the catalysis of lactoperoxidase [26]. It also reacts with chloride ions to produce hypochloric acid ( $\mathrm{HOCl})$ in the presence of myeloperoxidase [27]. Both HOSCN and $\mathrm{HOCl}$ are quite cytotoxic. The $\mathrm{H}_{2} \mathrm{O}_{2}$ oxidizes a ferrous ion $\left(\mathrm{Fe}^{2+}\right)$ to generate a ferric ion $\left(\mathrm{Fe}^{3+}\right)$, a hydroxyl radical, and a hydroxyl anion in the Fenton reaction [28]. Hydroxyl radicals are highly aggressive and able to cause oxidation of cellular macromolecules [29, 30].

Neutrophil extracellular trap (NET) is an effective bactericidal mechanism whose first step depends on the ROS that are derived from NADPH oxidase activation $[31,32]$. Neutrophil cytosolic factor 1 (an essential component of the $\mathrm{NOX}_{2}$ complex)-mutated mice lacked formation of NETs when they developed arthritis [33]. The priming step of NACHT, LRR, and PYD domains containing protein 3 (NLRP3) inflammasome expression requires ROS as well [34]. NETs and NLRP3 inflammasome are 2 effective mechanisms of neutrophil host defense. As a most abundant ROS, $\mathrm{H}_{2} \mathrm{O}_{2}$ may be a participator.

$\mathrm{H}_{2} \mathrm{O}_{2}$ is able to enhance the expression of inflammation-related genes and the synthesis of proinflammatory cytokines. TNF- $\alpha$ mRNA expression in human middle ear epithelial cells was significantly increased by treating with $\mathrm{H}_{2} \mathrm{O}_{2}$ at concentrations over $100 \mu \mathrm{M}$ [35]. The intragastric administration of $5 \% \mathrm{H}_{2} \mathrm{O}_{2}$ significantly increased the expression of TNF- $\alpha$, IL- $1 \beta$, and IL-5 mRNA [36]. It also induces secretion of proinflammatory molecules TNF- $\alpha$, macrophage chemokine protein-1, IL- 8 , and IFN- $\alpha$ in epithelial cells in a dose-dependent manner [37].

Patients with chronic granulomatous disease are hypersensitive to various bacterial and fungal infections due to defective NADPH oxidase activity. The inability of phagocytes to kill ingested pathogens or undergo apoptosis for the absence of $\mathrm{H}_{2} \mathrm{O}_{2}$ results in accumulation of bacteria-containing phagocytes and development of granulomas $[38,39]$. Defective $\mathrm{H}_{2} \mathrm{O}_{2}$ generation contributes to lasting inflammation and suggests that $\mathrm{H}_{2} \mathrm{O}_{2}$ plays an essential role in inflammation regulation.

\section{Cell Proliferation Stage}

Once infectious sources and cell fragments are removed, restoring the absent tissue becomes the subsequent task comprised mainly in 2 forms: reepithelialization and formation of granulating tissue. For reepithelialization to begin, keratinocytes need to change their ability of adhesion and mobility to migrate from surrounding tissue to the wound site and then proliferate. A scratch-wound model made up of keratinocyte culture showed that $\mathrm{H}_{2} \mathrm{O}_{2}$ promoted keratinocytes' mobility at a low concentration of about $500 \mu \mathrm{M}$ without any loss of the

Hydrogen Peroxide for Wound Treatment cells' viability [40]. The keratinocytes treated with $\mathrm{H}_{2} \mathrm{O}_{2}$ at a low concentration have enhanced epidermal growth factor receptor activation and ERK1/2 phosphorylation, which explains its higher potential of migration $[6,40]$.

Angiogenesis is a key step in formation of granulation tissue. By topical application of $10 \mathrm{mM} \mathrm{H}_{2} \mathrm{O}_{2}$ to rat excisional wounds, the wound closure rate was significantly increased by a strong promotion of angiogenesis and connective tissue regeneration [5]. Cyclooxygenase-derived products, particularly prostaglandin $\mathrm{E}_{2}$, play an important role in endothelial cell migration [41, 42], while $\mathrm{H}_{2} \mathrm{O}_{2}$ augmented cyclooxygenase- 2 protein synthesis in human endothelial cells [43]. In vitro, $\mathrm{H}_{2} \mathrm{O}_{2}$ can stimulate macrophages [44], retinal keratinocytes [45], and vascular smooth muscle cells [46] to release vascular endothelial growth factor which possesses a strong ability of promoting angiogenesis.

In zebrafish, $\mathrm{H}_{2} \mathrm{O}_{2}$ derived from wounded skin cells strengthened injury-induced peripheral sensory axon regeneration that helps to innervate healing skin [47]. Similarly, $\mathrm{H}_{2} \mathrm{O}_{2}$ in concentrations less than $500 \mu \mathrm{M}$ enhanced the release of heat shock protein (HSP70, HSP90) and fibroblast growth factor from cultured rat astrocytes, which contributes to neuron survival, neurite outgrowth, and angiogenesis [7]. Hence, $\mathrm{H}_{2} \mathrm{O}_{2}$ is probably favorable in both the structural and functional recovery of cutaneous wound.

\section{Tissue Remodeling Phase}

Early gestational fetal skin can undergo scarless repair for a lack of inflammation phase [48]. Therefore, the influence exerted by $\mathrm{H}_{2} \mathrm{O}_{2}$ on the inflammation phase may have a carryover effect to influence tissue remodeling.

$\mathrm{H}_{2} \mathrm{O}_{2}$ disturbs the balance between matrix metalloproteinases and tissue inhibitors of matrix metalloproteinases [49]. A study using a murine fetal wound repair model showed that $\mathrm{H}_{2} \mathrm{O}_{2}$ elevated the expression of transforming growth factor (TGF)-1 and enhanced proliferation of fibroblasts [50]. $\mathrm{NOX}_{2}$ is revealed to involve in the differentiation of human dermal fibroblast into myofibroblasts in response to TGF-1 [51]. $\mathrm{NOX}_{4}$ is also reported to be involved in collagen deposition for its stimulatory effect of TGF- $\beta_{1}$ [52] (Fig. 1).

\section{Current Clinical Use of Hydrogen Peroxide}

For clinical irrigation, $\mathrm{H}_{2} \mathrm{O}_{2}$ is usually $3 \%(975 \mu \mathrm{M})$, which oxidizes protein, nucleic acid, lipids of normal healthy cells, and microorganisms at the same time [53].

Med Princ Pract 2017;26:301-308

DOI: $10.1159 / 000475501$ 
Fig. 1. The roles of hydrogen peroxide $\left(\mathrm{H}_{2} \mathrm{O}_{2}\right)$ in wound healing course. TF, tissue factor; VEGF, vascular endothelial growth factor; Cox-2, cyclooxygenase-2; EFGR, epidermal growth factor receptor; TGF- $\beta_{1}$, transforming growth factor- $\beta_{1}$.

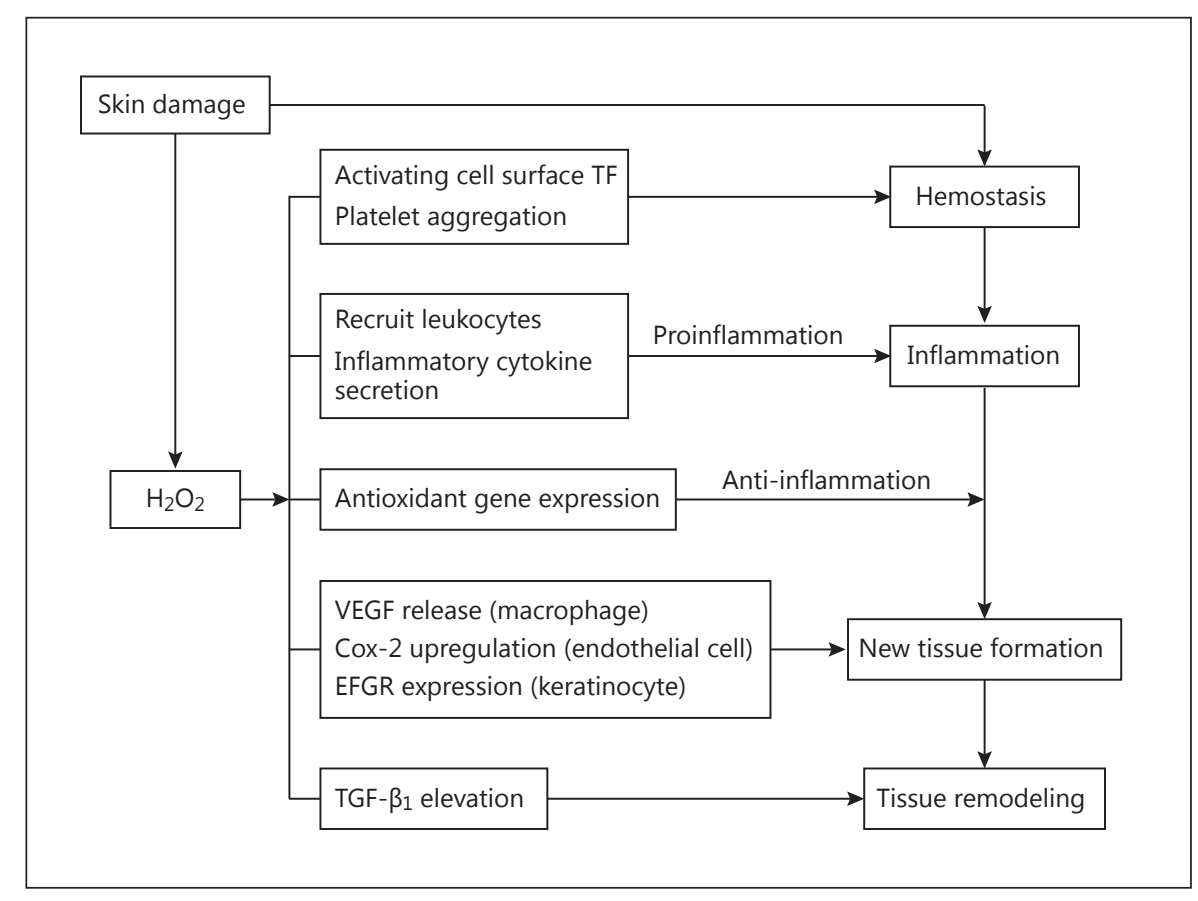

The use of $\mathrm{H}_{2} \mathrm{O}_{2}$ to disinfect wounds continues today, but no beneficial effect of $3 \% \mathrm{H}_{2} \mathrm{O}_{2}$ in promoting wound healing has been seen in the literature $[16,54]$. In addition, the killing ability of $\mathrm{H}_{2} \mathrm{O}_{2}$ on pathogenic bacteria like Pseudomonas aeruginosa is doubtful because catalases are reported to exist in their bodies [55]. $\mathrm{H}_{2} \mathrm{O}_{2}$ is also used regularly to prepare the bony bed in cemented arthroplasties as well as to achieve hemostasis in neurosurgery [56, 57]. It is also an adjunct hemostatic to topical epinephrine in patients with known platelet dysfunction after burn excision [58]. Equally important, it has an inherent risk of fatal oxygen embolism formation $[59,60]$.

Some drugs that contain $\mathrm{H}_{2} \mathrm{O}_{2}$ to treat cutaneous infection have been developed. In a cream formula, $\mathrm{LHP}^{\circledR}$, $1 \% \mathrm{H}_{2} \mathrm{O}_{2}$ is included in a stabilized form that allows a slow degradation and a prolonged effect [61]. $\mathrm{H}_{2} \mathrm{O}_{2}$ cream (Crystacide; Mipharm, Milan, Italy) is another formulation of $\mathrm{H}_{2} \mathrm{O}_{2} 1 \%$ in stabilized cream that has shown good antimicrobial effect and skin tolerability [62]. A prospective clinical trial demonstrated that wound cleansing with $2 \% \mathrm{H}_{2} \mathrm{O}_{2}$ on chronic-colonized burn wounds for $5 \mathrm{~min}$ followed by normal saline irrigation and grafting elevated the success rate of graft take when compared with the conventional method of debridement and skin grafting [63].

\section{Hydrogen Peroxide: Implications for Chronic Wound Treatment}

Chronic wounds are characterized by chronic inflammation which also appears in many chronic inflammatory diseases, such as diabetes mellitus, rheumatoid arthritis, periodontal disease, cardiovascular disease, and inflammatory bowel disease. A correct balance between $\mathrm{H}_{2} \mathrm{O}_{2}$ generation and detoxification mechanism must be properly maintained to avoid oxidative damages [64]. Defective leukocyte apoptosis and subsequent removal of apoptotic cells by phagocytes is thought to be important for the initiation and propagation of chronic inflammation. The role of NADPH oxidase-derived $\mathrm{H}_{2} \mathrm{O}_{2}$ to induce apoptosis of phagocytes and resolution of inflammation has been reported in a model of antigen-induced arthritis [65]. It is possible to take advantage of this function of $\mathrm{H}_{2} \mathrm{O}_{2}$ to regulate pathogenic inflammation in chronic wounds.

The $\mathrm{H}_{2} \mathrm{O}_{2}$ concentrations change in wound tissue influences the healing rate. In a murine model of wound healing, topical application of $50 \mathrm{mM} \mathrm{H}_{2} \mathrm{O}_{2}$ promoted wound closure while $3 \% \mathrm{H}_{2} \mathrm{O}_{2}(980 \mathrm{mM})$ delayed healing [16]. In a mouse model of excisional wounds, $10 \mathrm{mM}$ $\mathrm{H}_{2} \mathrm{O}_{2}$ promoted wound closure but $166 \mathrm{mM}$ retarded it when compared with control mice [5]. $\mathrm{H}_{2} \mathrm{O}_{2}$ can pass through the plasma membrane through specific aquapo- 
rin expressed on cells' membranes [8]. Pentafluorobenzenesulfonyl-fluorescein ( $\mathrm{HPF}$ ), a $\mathrm{H}_{2} \mathrm{O}_{2}$-selective chemical sensor showed an elevated intracellular redox level after exogenous $\mathrm{H}_{2} \mathrm{O}_{2}$ treatment [66]. By treating wild-type zebrafish larvae in the absence of injury with $3 \mathrm{mM} \mathrm{H}_{2} \mathrm{O}_{2}$ and then comparing their mRNA with an untreated group, 414 transcripts were found to be significantly upregulated while 256 were significantly downregulated [66]. Therefore, the application of exogenous $\mathrm{H}_{2} \mathrm{O}_{2}$ can lead to cellular behavior change. Apparently, $\mathrm{H}_{2} \mathrm{O}_{2}$ wound healing might be mainly based on acute injury models. There are few articles [37, 67] about the behavior of $\mathrm{H}_{2} \mathrm{O}_{2}$ in chronic wounds. The abnormal inflammation underlying a chronic wound may disturb the dynamic generation and clearance of $\mathrm{H}_{2} \mathrm{O}_{2}$ at the wound site.

Hypoxia is a key feature of many chronic wounds. The partial pressure of oxygen $\left(\mathrm{PO}_{2}\right)$ in nonspecified chronic wounds has been reported to be in the range of 5-20 mm $\mathrm{Hg}$ while typical values in healthy tissue are $30-50 \mathrm{~mm}$ $\mathrm{Hg}$ [68]. The production of ROS mediated by NADPHlinked oxygenase is a highly oxygen-dependent process: the half maximal velocity $(\mathrm{km})$ for NADPH-linked oxygenase with oxygen as a substrate is a $\mathrm{PO}_{2}$ value of $40-80$ $\mathrm{mm} \mathrm{Hg}$ [67]. The level of ROS is highly relevant with neutrophil antibacterial activity because it is responsible for neutrophil respiratory burst. Neutrophils were shown in vitro to lose their bacterial killing capacity at a $\mathrm{PO}_{2}$ level below $40 \mathrm{~mm} \mathrm{Hg} \mathrm{[67].} \mathrm{This} \mathrm{loss} \mathrm{could} \mathrm{be} \mathrm{attributed} \mathrm{to} \mathrm{the}$ reduction of ROS. The decrease in neutrophil antibacterial activity contributes to infection and this may partly explain the significant bacterial colonization in hypoxic chronic wounds. Therefore, long-time hypoxia could lead to ROS reduction. As a most abundant ROS, the reduction of $\mathrm{H}_{2} \mathrm{O}_{2}$ will impact negatively on wound healing, such as aggravated infection, decreased cytokines secretion, and abnormal inflammation.

Some treatments which generate low concentration $\mathrm{H}_{2} \mathrm{O}_{2}$ accelerate wound healing to a certain extent. Nonthermal atmospheric plasma (NAP) has been used in the clinical setting to accelerate wound healing [69]. Some changes exerted by NAP were abolished by catalase and the cells' responses to NAP treatment are similar to incubating in $\mathrm{H}_{2} \mathrm{O}_{2}$ in a similar concentration $[69,70]$, as exemplified by the plasma-induced profound extracellular trap formation (NET), which can be inhibited by the presence of catalase. However, adding an equivalent concentration of $\mathrm{H}_{2} \mathrm{O}_{2}$ cannot induce NET [71]. The NET formation may involve other constituents induced by plasma, but $\mathrm{H}_{2} \mathrm{O}_{2}$ is indispensable. In clinical practice, the application of NAP can achieve a significant reduction in

Hydrogen Peroxide for Wound Treatment bacterial load on chronic wounds and successfully remove the biofilm $[72,73]$. Its sterilization effect does not depend on the pathogen species and can even resist multidrug-resistant bacteria [74]. Some reports indicate that NAP can enhance the proliferation rate of basal keratinocytes and endothelial cells $[75,76]$. The 350 downregulated and 400 upregulated transcripts of keratinocytes after NAP treatment highlighted its powerful ability to influence gene expression [77].

Modern licensed dressings containing medical-grade honey like Surgihoney ${ }^{\circledR}$ and Revamil ${ }^{\circledR}$ have earned renewed interest in its clinical potential for conventional wound care [78, 79]. Laboratory investigations have shown that low concentrations of $\mathrm{H}_{2} \mathrm{O}_{2}$ are normally generated in these honeys when they are diluted. Glucose oxidase (an enzyme secreted into honey by worker bees) oxidizes glucose to gluconic acid with the release of $\mathrm{H}_{2} \mathrm{O}_{2}$ [78]. The antimicrobial ability of honey is partly contributed to $\mathrm{H}_{2} \mathrm{O}_{2}$. In a study testing the antimicrobial activity and the maximum output of $\mathrm{H}_{2} \mathrm{O}_{2}$ among 3 honey prototypes, there was a linear relationship between them. The more $\mathrm{H}_{2} \mathrm{O}_{2}$ the honey produces, the stronger antimicrobial ability it has [79]. Some biologically modified honey has also been reported to stimulate monocytes to secrete cytokines like TNF- $\alpha$, IL- $1 \beta$, and IL- 6 and it may be attributed to $\mathrm{H}_{2} \mathrm{O}_{2}$ [80].

\section{Hydrogen Peroxide Could Be a Target for Wound Treatment}

One of the priorities of chronic wound treatment is to form a favorable microenvironment that is receptive to therapies. Therapies that correct $\mathrm{H}_{2} \mathrm{O}_{2}$ to an appropriate level may help wound healing through ameliorating wound redox environment.

However, more basic experiments and clinical trials are needed to testify this hypothesis. First, it should be explored whether there are abnormalities in the distribution and concentration of $\mathrm{H}_{2} \mathrm{O}_{2}$ in chronic wounds. Second, new methods to regulate $\mathrm{H}_{2} \mathrm{O}_{2}$ more stably and precisely should be further researched to make treatment more standardized.

\section{Potential Future Use}

Uncontrolled production or decomposition of $\mathrm{H}_{2} \mathrm{O}_{2}$ is likely to result in tissue injury and has been associated with increased susceptibility to diseases due to the unbal-

Med Princ Pract 2017;26:301-308

DOI: $10.1159 / 000475501$ 
anced redox homeostasis. Further study about the critical role of $\mathrm{H}_{2} \mathrm{O}_{2}$ in inflammation initiation, development, and resolution could help precise regulation of inflammation progression. The therapeutic effect of $\mathrm{H}_{2} \mathrm{O}_{2}$ might not be limited to only chronic wound, but also applied to other diseases characterized by abnormal inflammation.

\section{Conclusion}

Normal wound healing is a carefully controlled balance of destructive processes necessary to remove damaged tissue and repair processes which lead to new tissue formation. The dynamic change of $\mathrm{H}_{2} \mathrm{O}_{2}$ in wound tissue helps to keep the balance during the wound-healing course. $\mathrm{H}_{2} \mathrm{O}_{2}$ promotes oxidative stress as well as resolves inflammation, which makes it a bidirectional inflamma- tion regulator. Uncontrolled $\mathrm{H}_{2} \mathrm{O}_{2}$ generation will result in chronic inflammation which contributes to delayed wound healing. Through further research upon its immune regulatory function, some therapies taking $\mathrm{H}_{2} \mathrm{O}_{2}$ as a target can be invented to promote chronic wound healing.

\section{Acknowledgment}

We would like to thank the Natural Science Foundation of China $(81272111,81671917)$ for their financial support.

\section{Disclosure Statement}

The authors report no conflicting interests.

\section{References}

1 Appenzeller-Herzog C, Bánhegyi G, Bogeski I, et al: Transit of $\mathrm{H}_{2} \mathrm{O}_{2}$ across the endoplasmic reticulum membrane is not sluggish. Free Radic Biol Med 2016;94:157-160.

2 Niethammer P, Grabher C, Look AT, et al: A tissue-scale gradient of hydrogen peroxide mediates rapid wound detection in zebrafish. Nature 2009;459:996-999.

3 van der Vliet A, Janssen-Heininger YM: Hydrogen peroxide as a damage signal in tissue injury and inflammation: murderer, mediator, or messenger? J Cell Biochem 2014;115: 427-435.

4 Marinho HS, Real C, Cyrne L, et al: Hydrogen peroxide sensing, signaling and regulation of transcription factors. Redox Biol 2014;2:535562.

5 Loo AE, Wong YT, Ho R, et al: Effects of hydrogen peroxide on wound healing in mice in relation to oxidative damage. PLoS One 2012; 7:e49215.

6 Loo AE, Halliwell B: Effects of hydrogen peroxide in a keratinocyte-fibroblast co-culture model of wound healing. Biochem Biophys Res Commun 2012;423:253-258.

7 Ito J, Nagayasu Y, Hoshikawa M, et al: Enhancement of FGF-1 release along with cytosolic proteins from rat astrocytes by hydrogen peroxide. Brain Res 2013;1522:12-21.

8 Bienert GP, Schjoerring JK, Jahn TP, et al: Membrane transport of hydrogen peroxide. Biochim Biophys Acta 2006;1758:994-1003.

9 Marschall R, Tudzynski P: Reactive oxygen species in development and infection processes. Semin Cell Dev Biol 2016;57:138-146.

10 Espinosa-Diez C, Migue IV, Mennerich D, et al: Antioxidant responses and cellular adjustments to oxidative stress. Redox Biol 2015;6: 183-197.
11 Panday A, Sahoo MK, Osorio D, et al: NADPH oxidases: an overview from structure to innate immunity-associated pathologies. Cell Mol Immunol 2015;12:5-23.

12 Graham KA, Kulawiec M, Owens KM, et al: NADPH oxidase 4 is an oncoprotein localized to mitochondria. Cancer Biol Ther 2010;10: 223-231.

13 Laurindo FR, Araujo TL, Abrahao TB, et al: Nox NADPH oxidases and the endoplasmic reticulum. Antioxid Redox Signal 2014;20: 2755-2775.

14 El-Benna J, Dang PM, Gougerot-Pocidalo MA: Priming of the neutrophil NADPH oxidase activation: role of $\mathrm{p} 47 \mathrm{phox}$ phosphorylation and NOX2 mobilization to the plasma membrane. Semin Immunopathol 2008;30: 279-289.

15 Sen CK, Roy S: Redox signals in wound healing. Biochim Biophys Acta 2008;1780:13481361.

16 Roy S, Khanna S, Nallu K, et al: Dermal wound healing is subject to redox control. Mol Ther 2006;13:211-220.

17 Kim MH, Kim MH, Liu W, et al: Dynamics of neutrophil infiltration during cutaneous wound healing and infection using fluorescence imaging. J Invest Dermatol 2008;128: 1812-1820.

18 Segal AW, Geisow M, Garcia R, et al: The respiratory burst of phagocytic cells is associated with a rise in vacuolar $\mathrm{pH}$. Nature 1981; 290:406-409.

19 Reeves EP, Lu H, Jacob HL, et al: Killing activity of neutrophils is mediated through activation of proteases by $\mathrm{K}^{+}$flux. Nature 2002;416: 291-297.
20 Shi MM, Chong I, Godleski JJ, et al: Regulation of macrophage inflammatory protein-2 gene expression by oxidative stress in rat alveolar macrophages. Immunology 1999;97: 309-315.

21 Shi MM, Godleski JJ, Paulauskis JD, et al: Regulation of macrophage inflammatory protein1alpha mRNA by oxidative stress. J Biol Chem 1996;271:5878-5883.

22 Jaramillo M, Olivier M: Hydrogen peroxide induces murine macrophage chemokine gene transcription via extracellular signal-regulated kinase- and cyclic adenosine $5^{\prime}$-monophosphate (cAMP)-dependent pathways: involvement of NF-kappa B, activator protein 1, and cAMP response element binding protein. J Immunol 2002;169:7026-7038.

23 Fraticelli A, Serrano CV Jr, Bochner BS, et al: Hydrogen peroxide and superoxide modulate leukocyte adhesion molecule expression and leukocyte endothelial adhesion. Biochim Biophys Acta 1996;1310:251-259.

$24 \mathrm{Lu} \mathrm{H}$, Youker K, Ballantyne C, et al: Hydrogen peroxide induces LFA-1-dependent neutrophil adherence to cardiac myocytes. Am J Physiol Heart Circ Physiol 2000;278:H835H842.

25 Mohd Nasir N, Lee BK, Yap SS, et al: Cold plasma inactivation of chronic wound bacteria. Arch Biochem Biophys 2016;605:76-85.

26 Wijkstrom-Frei C, El-Chemaly S, Ali-Rachedi R, et al: Lactoperoxidase and human airway host defense. Am J Respir Cell Mol Biol 2003; 29:206-212.

27 Schreml S, Landthaler M, Schäferling $M$, et al: A new star on the $\mathrm{H}_{2} \mathrm{O}_{2}$ rizon of wound healing? Exp Dermatol 2011;20:229-231. 
28 Tovmasyan A, Sheng H, Weitner T, et al: Design, mechanism of action, bioavailability and therapeutic effects of Mn porphyrin-based redox modulators. Med Princ Pract 2013;22: 103-130.

29 Kanta J: The role of hydrogen peroxide and other reactive oxygen species in wound healing. Acta Medica (Hradec Kralove) 2011;54: 97-101.

30 Schafer M, Werner S: Oxidative stress in normal and impaired wound repair. Pharmacol Res 2008;58:165-171.

31 Cooper PR, Palmer LJ, Chapple IL: Neutrophil extracellular traps as a new paradigm in innate immunity: friend or foe? Periodontol 2000 2013;63:165-197.

32 Muñoz-Caro T, Lendner M, Daugschies A, et al: NADPH oxidase, MPO, NE, ERK1/2, p38 MAPK and $\mathrm{Ca}^{2+}$ influx are essential for Cryptosporidium parvum-induced NET formation. Dev Comp Immunol 2015;52:245-254.

33 Holmdahl R, Sareila O, Olsson LM, et al: Ncf1 polymorphism reveals oxidative regulation of autoimmune chronic inflammation. Immunol Rev 2016;269:228-247.

34 Bauernfeind F, Bartok E, Rieger A, et al: Cutting edge: reactive oxygen species inhibitors block priming, but not activation, of the NLRP3 inflammasome. J Immunol 2011;187: 613-617.

35 Song JJ, Lim HW, Kim K, et al: Effect of caffeic acid phenethyl ester (CAPE) on $\mathrm{H}_{2} \mathrm{O}_{2}$ induced oxidative and inflammatory responses in human middle ear epithelial cells. Int J Pediatr Otorhinolaryngol 2012;76:675-679.

36 Cui Z, Yin J, Wang L, et al: Effects of pro-inflammatory cytokines and antioxidants expression in the jejunum of mice induced by hydrogen peroxide. Int Immunopharmacol 2016;31:9-14.

37 Bryan N, Ahswin H, Smart N, et al: Reactive oxygen species (ROS) - a family of fate deciding molecules pivotal in constructive inflammation and wound healing. Eur Cell Mater 2012;24:249-265.

38 Roos D: Chronic granulomatous disease. $\mathrm{Br}$ Med Bull 2016;118:50-63.

39 Fridovich I: Oxygen: how do we stand it? Med Princ Pract 2013;22:131-137.

40 Loo AE, Ho R, Halliwell B: Mechanism of hydrogen peroxide-induced keratinocyte migration in a scratch-wound model. Free Radic Biol Med 2011;51:884-892.

41 Kuwano T, Nakao S, Yamamoto H, et al: Cyclooxygenase 2 is a key enzyme for inflammatory cytokine-induced angiogenesis. FASEB J 2004; 18:300-310.

42 Rao R, Redha R, Macias-Perez I, et al: Prostaglandin E2-EP4 receptor promotes endothelial cell migration via ERK activation and angiogenesis in vivo. J Biol Chem 2007;282: 16959-16968.

43 Eligini S, Arenaz I, Barbieri SS, et al: Cyclooxygenase- 2 mediates hydrogen peroxide-induced wound repair in human endothelial cells. Free Radic Biol Med 2009;46:14281436.
44 Cho M, Hunt TK, Hussain MZ, et al: Hydrogen peroxide stimulates macrophage vascular endothelial growth factor release. Am J Physiol Heart Circ Physiol 2001;280:H2357H2363.

45 Brauchle M, Funk JO, Kind P, et al: Ultraviolet $\mathrm{B}$ and $\mathrm{H}_{2} \mathrm{O}_{2}$ are potent inducers of vascular endothelial growth factor expression in cultured keratinocytes. J Biol Chem 1996;271: 21793-21797.

46 Ruef J, Hu ZY, Yin LY, et al: Induction of vascular endothelial growth factor in balloon-injured baboon arteries. A novel role for reactive oxygen species in atherosclerosis. Circ Res 1997;81:24-33.

47 Rieger S, Sagasti A: Hydrogen peroxide promotes injury-induced peripheral sensory axon regeneration in the zebrafish skin. PLoS Biol 2011;9:e1000621.

48 Longaker MT, Whitby DJ, Adzick NS, et al: Studies in fetal wound healing, VI. Second and early third trimester fetal wounds demonstrate rapid collagen deposition without scar formation. J Pediatr Surg 1990;25:63-68; discussion 68-69.

49 Hemmerlein B, Johanns U, Halbfass J, et al: The balance between MMP-2/-9 and TIMP$1 /-2$ is shifted towards MMP in renal cell carcinomas and can be further disturbed by hydrogen peroxide. Int J Oncol 2004;24:10691076.

50 Wilgus TA, Bergdall VK, Dipietro LA, et al: Hydrogen peroxide disrupts scarless fetal wound repair. Wound Repair Regen 2005;13: 513-519.

51 Zhang GY, Wu LC, Dai T, et al: NADPH oxidase- 2 is a key regulator of human dermal fibroblasts: a potential therapeutic strategy for the treatment of skin fibrosis. Exp Dermatol 2014;23:639-644.

52 Chan EC, Peshavariya HM, Liu GS, et al: Nox4 modulates collagen production stimulated by transforming growth factor $\beta_{1}$ in vivo and in vitro. Biochem Biophys Res Commun 2013;430:918-925.

53 Yamada Y, Mokudai T, Nakamura K, et al: Topical treatment of oral cavity and wounded skin with a new disinfection system utilizing photolysis of hydrogen peroxide in rats. J Toxicol Sci 2012;37:329-335.

54 Spear M: Wound cleansing: solutions and techniques. Plast Surg Nurs 2011;31:29-31.

55 Thomas GW, Rael LT, Bar-Or R, et al: Mechanisms of delayed wound healing by commonly used antiseptics. J Trauma 2009;66: 82-90; discussion 90-81.

56 Kolt JD, Robin DA, Carr AM, et al: Safety of autologous drainage blood reinfusion following total knee arthroplasty prepared with hydrogen peroxide. Knee 2007;14:12-18.

57 Ackland DC, Yap V, Ackland ML, et al: Pulselavage brushing followed by hydrogen peroxide-gauze packing for bone-bed preparation in cemented total hip arthroplasty: a bovine model. J Orthop Surg (Hong Kong) 2009;17: 296-300.
58 Potyondy L, Lottenberg L, Anderson J, et al: The use of hydrogen peroxide for achieving dermal hemostasis after burn excision in a patient with platelet dysfunction. J Burn Care Res 2006;27:99-101.

59 Beattie C, Harry LE, Hamilton SA, et al: Cardiac arrest following hydrogen peroxide irrigation of a breast wound. J Plast Reconstr Aesthet Surg 2010;63:e253-e254.

60 Mut M, Yemisci M, Gursoy-Ozdemir Y, et al: Hydrogen peroxide-induced stroke: elucidation of the mechanism in vivo. J Neurosurg 2009;110:94-100.

61 Toth T, Broström H, Båverud V, et al: Evaluation of $\mathrm{LHP}(\mathrm{R})$ ( $1 \%$ hydrogen peroxide) cream versus petrolatum and untreated controls in open wounds in healthy horses: a randomized, blinded control study. Acta Vet Scand 2011;53:45.

62 Capizzi R, Landi F, Milani M, et al: Skin tolerability and efficacy of combination therapy with hydrogen peroxide stabilized cream and adapalene gel in comparison with benzoyl peroxide cream and adapalene gel in common acne. A randomized, investigator-masked, controlled trial. Br J Dermatol 2004;151:481484.

63 Mohammadi AA, Seyed Jafari SM, Kiasat M, et al: Efficacy of debridement and wound cleansing with $2 \%$ hydrogen peroxide on graft take in the chronic-colonized burn wounds; a randomized controlled clinical trial. Burns 2013;39:1131-1136.

64 De Deken X, Corvilain B, Dumont JE, et al: Roles of DUOX-mediated hydrogen peroxide in metabolism, host defense, and signaling. Antioxid Redox Signal 2014;20:2776-2793.

65 Lopes F, Coelho FM, Costa VV, et al: Resolution of neutrophilic inflammation by $\mathrm{H}_{2} \mathrm{O}_{2}$ in antigen-induced arthritis. Arthritis Rheum 2011;63:2651-2660.

66 Lisse TS, King BL, Rieger S: Comparative transcriptomic profiling of hydrogen peroxide signaling networks in zebrafish and human keratinocytes: implications toward conservation, migration and wound healing. Sci Rep 2016;6:20328.

67 Schreml S, Szeimies RM, Prantl L, et al: Oxygen in acute and chronic wound healing. $\mathrm{Br} \mathrm{J}$ Dermatol 2010;163:257-268.

68 Kendall AC, Whatmore JL, Winyard PG, et al: Hyperbaric oxygen treatment reduces neutrophil-endothelial adhesion in chronic wound conditions through S-nitrosation. Wound Repair Regen 2013;21:860-868.

69 Bekeschus S, Schmidt A, Weltmann K-D, et al: The plasma jet kINPen - a powerful tool for wound healing. Clin Plasma Med 2016;4: 19-28.

70 Bekeschus S, Kolata J, Winterbourn C, et al: Hydrogen peroxide: a central player in physical plasma-induced oxidative stress in human blood cells. Free Radic Res 2014;48:542-549.

71 Bekeschus S, Winterbourn CC, Kolata J, et al: Neutrophil extracellular trap formation is elicited in response to cold physical plasma. J Leukoc Biol 2016;100:791-799.
Hydrogen Peroxide for Wound

Treatment
Med Princ Pract 2017;26:301-308

DOI: $10.1159 / 000475501$ 
72 Isbary G, Heinlin J, Shimizu T, et al: Successful and safe use of 2 min cold atmospheric argon plasma in chronic wounds: results of a randomized controlled trial. $\mathrm{Br} J$ Dermatol 2012;167:404-410.

73 Fricke K, Koban I, Tresp H, et al: Atmospheric pressure plasma: a high-performance tool for the efficient removal of biofilms. PLoS One 2012; 7:e42539.

74 Daeschlein G, Scholz S, Ahmed R, et al: Skin decontamination by low-temperature atmospheric pressure plasma jet and dielectric barrier discharge plasma. J Hosp Infect 2012;81: 177-183.
75 Hasse S, Duong Tran T, Hahn O, et al: Induction of proliferation of basal epidermal keratinocytes by cold atmospheric-pressure plasma. Clin Exp Dermatol 2016;41:202-209.

76 Kalghatgi S, Friedman G, Fridman A, et al: Endothelial cell proliferation is enhanced by low dose non-thermal plasma through fibroblast growth factor-2 release. Ann Biomed Eng 2010;38:748-757.

77 Schmidt A, Dietrich S, Steuer A, et al: Nonthermal plasma activates human keratinocytes by stimulation of antioxidant and phase II pathways. J Biol Chem 2015;290:67316750.
78 Cooper R: Honey as an effective antimicrobial treatment for chronic wounds: is there a place for it in modern medicine? Chronic Wound Care Management Res 2014;1:15.

79 Cooke J, Dryden M, Patton T, et al: The antimicrobial activity of prototype modified honeys that generate reactive oxygen species (ROS) hydrogen peroxide. BMC Res Notes 2014;8:20.

80 Tonks AJ, Cooper RA, Jones KP, et al: Honey stimulates inflammatory cytokine production from monocytes. Cytokine 2003;21:242-247. 